\title{
Establishment of Standardization Parameters for Herbal Formulation, Swarasa Bhvit Amalaka Churnam
}

\author{
Vihangesh Kumar Dixit ${ }^{* 1}$, Raghuveer Irchhaiya ${ }^{2}$, Nandlal Singh ${ }^{2}$, Rishikesh Gupta ${ }^{2}$ \\ 1 School of Pharmacy, Monad University, Hapur (U.P.) India \\ 2 Institute of Pharmacy, Bundelkhand University Jhansi, (U.P.) India
}

\section{ABSTRACT}

Herbal formulations are very useful for human health because of their natural and simple processing. A quality herbal formulation must pass the test for their characteristic properties. Inspite of the large number of Ayurvedic formulations are available in the mark et, standards of their quality are yet to be laid. Amlaka churnam or amalaki rasayanam is a swarasa bhavita, important herbal formulation used for treatment related to immunity systems of human body. In addition to this it is also used for nurturing of skin, heart, eye and stomach. The main ingredient of amalaka churnam is amla (Embalica officinalis) family Euphorbiaceae. Though amalaka churnam is described in many classical Ayurvedic granthas, but there are minor differences in their formulations. Also marketed formulations of amalaki rasayanam by manufacturers do not have description about its standardization. Therefore, it is necessary to develop standard parameters for establishment of quality of the formulation. In this work, a standardization of herbal formulations of amalaka churnam is reported in terms of organoleptic evaluation of ingredients with rasayana formulation, loss of drying analysis, foreign matter, phytochemical screening, $\mathrm{pH}$ estimation, evalu ation of ash value, extractive value and rheological evaluation.
\end{abstract}

Keywords: Bhvit, amalaka Churnam, Organoleptic, rheological etc.

Article Info: Received 11 July 2019; Review Completed 21 August 2019; Accepted 25 August 2019; Available online 30 Aug 2019

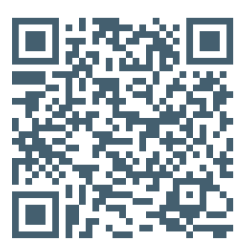

\section{Cite this article as:}

Dixit VK, Irchhaiya R, Singh N, Gupta R, Establishment of Standardization Parameters for Herbal Formulation, Swarasa Bhvit Amalaka Churnam, Journal of Drug Delivery and Therapeutics. 2019; 9(4-A):108-111 http://dx.doi.org/10.22270/jddt.v9i4-A.3421

Vihangesh Kumar Dixit, School of Pharmacy, Monad University, Hapur (U.P.) India

\section{INTRODUCTION}

Now a day, a common interest of people has been inclined towards utilization of naturally originated formulations due to their negligible adverse effects. An Ayurvedic medicinal system rasayana refers as medication which is used to increase rasa and dhatus to the body for boosting body system. Rasayana promote cure from diseases by improving function of body immunity system[1]. The term rasayana generally considered various fruit minerals, herbs and other medicine such as pippli, bahera, amla, silajeet etc which promote health and aging. It boosts vital force of like (Oja). \& also boosts shukra dhatu (semen production). According to ancient concept of ayurveda rasayan improve rasa, rakta, mansa, meda, asti, massa, shukra[2]. There are many type of rasayana used in ayurvedic medicine system for example pipplirasayan, Dhatritilrasayan, amalkirasayana, Haritakirasayan, vidangarasayan, Silajeetrasayan, brahmirasayanrasayan, dhartri churn rasayana, triphalarasayana[3] and ashvagandharasayan.
Rasayan Ayurvedic formulations are made from natural ingredients are multi targeted while modern synthetic medicines are single targeted and toxic effects[4]. The quality of traditional rasayan formulations can improved by utilizing modern scientific methods[5].

Amalkirasayan churnam (amalaka churnam) is an ancient Ayurvedic formulation. The formulation of amalaki churnam is described in Charak Samhita, Sushruta Samhita, Chakradutta, Bhaisjayaratnavali. They formulate amalakirasayana churnam for treatment of gastric problems, rejuvenating actions, nourshing the skin, hair and aphrodisiac purpose. The main ingredient of amalakirasayana is amla or dhatri (Embilica officinalis), dry fruit powder and amlaswarasa.

All the Ayurvedic granthas formulate amalakirasayana in different manner. The marketed amalaka formulations show difference in amount of ingredients and lack quality establishment parameters in product descriptions. Thus, 
there is a need for development of standardization parameters for Amlaka churnam[6,7].

This works establishment of quality standard parameters of amalaka churnam have been presented. The parameters selected from WHO guidelines are organoleptic analysis[8], evaluation of loss on drying and presence of foreign matter, physio chemical analysis[9], $\mathrm{pH}$ determination, establishment of ash value, extracted value and rheological analysis[10].The results of study are useful for testing of formulation and conducting advance research on formulations.

\section{MATERIALS AND METHODS}

Raw material used for preparation of above-mentioned formulation, amla collected from farm house of bundelkhand region and identified morphologically, microscopically and compared with their standard monographs for authentication.

\section{Preparation of formulation,}

Dhatrifruits (Embilica officinalis) firstly crushed then seed has been removed. Seedless dhatri fruits then dried. To obtain powder form ( 80 mesh size), the dried dhatri fuits grinded

Fresh dhatri fruits have been collected for preparing juice. The juice has been prepared by crushing fresh dhatri fruit followed by filtering using muslin cloth.

Both powdered dhatri fruits and juice dhatri fruits have been mixed in the ratio of $1: 1$. Then, mixture has been titurated for 20 minutes. The titurated mixture then dried at $40^{\circ} \mathrm{C}$ in hot air over oven. The dried mixture then crushed and powdered ( 80 mesh size). The step is called bhavna in ayurveda. The bhavna step is repeated 20 times and finally obtained powder is ready material for establishment of standardization parameters.

\section{Organoleptic analysis}

Organoleptic analysis included color, odour, taste, touch analysis of ingredients and formulations. Colors are examined at daylight by naked eye. The odour of samples of rasayana was tested by smelling and kept 2 minutes interval between two tests to nullify the nullifying effect of previous sample smelling. The all samples were tasted with time interval of 15 minutes. All the samples were also verified for their touch profiles. All the analysis is repeated by another person to recheck the results.

\section{Loss on drying}

To determine loss of drying, a $1 \mathrm{~g}$ of air-cooled formulation is placed in a standard bottle. The sample is weighted with bottle. The bottle with sample has been dried using an oven at $100-105^{\circ} \mathrm{C}$ for one hour. The dried sample is again weighted with bottle and the difference of weights before drying and after drying is measured as loss on drying.

\section{Loss on drying and identification of foreign matter}

To determine loss of drying, a $1 \mathrm{~g}$ of air-cooled formulation is placed in a standard bottle. The sample is weighted with bottle. The bottle with sample has been dried using an oven at $100-105^{\circ} \mathrm{C}$ for one hour. The dried sample is again weighted with bottle and the difference of weights before drying and after drying is measured as loss on drying. For determination of foreign matter, a sample of $5 \mathrm{~g}$ is taken and spread in a thin layer and foreign matted ware sorted using a magnifier lens (10x). The sample then passed through sieve of no. 250. The separated foreign matter is weighted to provide the percentage of its presence.

\section{Phytochemical screening}

The phytochemical studies were carried out to determine presence of tannin, alkaloids, phenolics, protein, glycoside, carbohydrate, terpene and soponin[11]. Many tastes hae been conducted like gelatin test, lead acetate test, ferric chloride test, Mayer's, dragendroff's, Millon's biuret and Ninhydrin test, Borntrangr's test, iodine test, molisch's test, Fehling's test, Libermon's test, Salkoweski test, Froth test etc.

\section{pH Determination}

To determine $\mathrm{pH}$ value of the material amla swaras, $10 \%$ solution of amla churna and its formulation prepared to determine $\mathrm{pH}$ value using $\mathrm{pH}$ paper and $\mathrm{pH}$ meter.

\section{Ash Value determination}

To determine total Ash value take 2 gm amlaka churnam lab and marketed formulation and its ingredients on silica dishes ignited in muffle furnace at $550-600^{\circ} \mathrm{C}$ until it is indicating the free from carbon than cooled and calculated percentage of total ash with reference to the air dried material.

\section{Acid insoluble Ash Value determination}

The ash amlaka churnam lab and marketed formulation and its ingredients were boiled for 5 min with dil. HCL and insoluble matter were collected, washed with hot water than filtered ignited to a constant weight and calculated the percentage with reference to the air dried drug.

\section{Water soluble Ash Value determination}

The total ash obtained from amlaka churnam lab and marketed formulation and its ingredients were boiled for 5 min with10 $\mathrm{ml}$ water and insoluble matter were collected, washed with hot water than filtered ignited to a constant weight. To determine water soluble ash value, the weight of insoluble matter as subtracted from total ash value. The percentage of water-soluble ash was calculated from air dry formulations and its ingredients.

\section{Extractive values evaluation}

The extractive values of amla and amlaki rasayana were recorded in alcohol and water using cold maceration method. Wight $3 \mathrm{gm}$ of air dried amla churna and formulations were macerated $100 \mathrm{ml}$ with solvents (alcohol and water) in closed flask for 24 hours and were shaken frequently during 3 hours then allowed to stand for 18 hours. The mixture was filtered quickly to avoid loss of solvent due to evaporation than take twenty-five $\mathrm{ml}$ of in tared flat bottomed dish and evaporate to dryness at $105^{\circ} \mathrm{C}$ to a constant weight and percent extractive values (alcoholic and water) were calculative with reference to air dried ingredients and formulation.

\section{Rheological evaluation}

All the samples of materials were subjected to tests for rheological evaluation of the samples in terms of tap density, bulk density, angle of repose,

\section{(i) Bulk density}

To measure bulk density, mass of the powder and volume of the powder is required. The powder put into a $100 \mathrm{ml}$ cylinder. The cylinder is dropped over a wooden plank again and again keeping time interval of 2 seconds from $2 \mathrm{~cm}$ height. Powder in cylinder is weighted again. The volume of the cylinder is measured in $\mathrm{cm}^{3}$. The bulk density is obtained by dividing weight of the cylinder by volume in $\mathrm{cm}^{3}$. 


\section{(ii) Tap density}

The powder of a sample is carefully taken into $100 \mathrm{ml}$ cylinder. To reduce volume of the material, the cylinder is dropped again and again over a wooden plank from height of $2 \mathrm{~cm}$ till there is no significant decrease in volume. Tap density is obtained by ratio of weight of sample in gm to final volume of the cylinder in $\mathrm{cm}^{3}$.

\section{(iii) Angle of repose}

In order to execute this test, a glass funnel is kept by using a clamp with a ring support. The glass placed is placed on a micro lab jack. $100 \mathrm{gm}$ powder is taken into the funnel and the orifice of the funnel is closed by a thumb. To measure the angle of repose, the thumb is removed from the funnel. While removing the thumb, about $6.5 \mathrm{~mm}$ difference is maintained between funnel orifice and top of the powder pile. When complete powder comes out of the funnel the angle of heap to horizontal plane is measured, this heap angle is called angle of repose.

\section{RESULTS AND DISCUSSION}

In order to determine standardization parameters, amalaka rasayana churnam is under undergone through all the methods discussed previously. In this section, the results obtained after the proves of evaluation has been presented In order to represent name of samples following abbreviations have been used; AM (Amla Churn), AMS (Amla Swarasa) AMR-I (Amalki Rasayan Churn-I), AMR-II (Amalki Rasayan Churn-II), AMR-III (Amalki Rasaya Churn-III), MAMR (Marked Amalki Rasayan Churn).Organoleptic analysis of the formulation and all raw ingredients were evaluated by earlier discussed method. The organoleptic analysis summarized in Table 1 .

Table 1: Organoleptic Evaluation of Amalki Rasayan Churn and its Ingredients

\begin{tabular}{|c|c|c|c|c|c|}
\hline S.No. & Name & Color & Odour & Taste & Touch \\
\hline $\mathbf{1 .}$ & AM & Brown & Specific & Sour \& Sweet & Smooth \\
\hline $\mathbf{2 .}$ & AMS & Green & Specific & Sour \& Sweet & Soft Fluidy \\
\hline $\mathbf{3 .}$ & AMR-I & Dark Brown & Specific & Sour \& Acidic & Smooth \\
\hline $\mathbf{4 .}$ & AMR-II & Dark Brown & Specific & Sour \& Acidic & Smooth \\
\hline $\mathbf{5 .}$ & AMR-III & Dark Brown & Specific & Sour \& Acidic & Smooth \\
\hline $\mathbf{6 .}$ & MAMR & Dark Brown & Specific & Sour \& Acidic & Smooth \\
\hline
\end{tabular}

Amla Churna and its lab batches with its raw materials were evaluated for loss on drying and foreign matter through the method discussed earlier the result of both recorded and tabulated in Table 2.

Table 2: Loss on drying \& foreign matter in Amalki Rasayan Churnam \& its Ingredients

\begin{tabular}{|c|c|c|c|}
\hline S.No. & Name & \%LOD* & \% Foreign Matter* \\
\hline $\mathbf{1 .}$ & AM & $3.54 \pm 0.488$ & $1.42 \pm 0.242$ \\
\hline $\mathbf{2 .}$ & AMS & $83.58 \pm 4.558$ & $1.01 \pm 0.151$ \\
\hline $\mathbf{3 .}$ & AMR-I & $3.51 \pm 0.321$ & Nil \\
\hline $\mathbf{4 .}$ & AMR-II & $3.43 \pm 0.366$ & Nil \\
\hline $\mathbf{5 .}$ & AMR-III & $3.22 \pm 0.324$ & Nil \\
\hline $\mathbf{6 .}$ & MAMR & $3.60 \pm 0.412$ & Nil \\
\hline
\end{tabular}

*mean \pm S.D. $(\mathbf{n}=6)$

Further, results of phytochemical analysis of raw material and laboratory formulations with marketed formulation of Amlaka Churna are recorded in Table 3 .

Table 3: Phyto Chemical Screening of Amalki Rasayan Churnam \& its Ingredients

\begin{tabular}{|l|c|c|c|c|c|c|c|c|}
\hline Name & Tannin & Alkaloids & Phenolics & Protein & Glycoside & Carbohydrate & Terpene & Saponin \\
\hline AM & + & + & + & - & + & + & - & + \\
\hline AMS & + & + & + & - & + & + & - & + \\
\hline AMR-I & + & + & + & - & + & + & - & + \\
\hline AMR-II & + & + & + & - & + & + & - & + \\
\hline AMR-III & + & + & + & - & + & + & - & + \\
\hline MAMR & + & + & + & - & + & + & - & + \\
\hline
\end{tabular}

$\mathrm{pH}$ value of all samples of Amla churna and amalaka rasayana including marketed formulations has been evaluated. $\mathrm{pH}$ value of samples has been evaluated using $\mathrm{pH}$ paper and $\mathrm{pH}$ meter. The average of these two values is shown in

Table 4

Table 4: pH of Amalki Rasayan Churnam \& its Ingredients

\begin{tabular}{|l|c|c|c|}
\hline \multicolumn{1}{|c|}{ S.No. } & Name & pH Paper & pH Meter \\
\hline $\mathbf{1 .}$ & AM & 4 & 3.8 \\
\hline $\mathbf{2 .}$ & AMS & 3 & 2.8 \\
\hline $\mathbf{3 .}$ & AMR-I & 4 & 3.2 \\
\hline $\mathbf{4 .}$ & AMR-II & 4 & 3.3 \\
\hline $\mathbf{5 .}$ & AMR-III & 4 & 3.4 \\
\hline $\mathbf{6 .}$ & MAMR & 4 & 3.3 \\
\hline
\end{tabular}


Total Ash value has been determined by using 2 gm amlaka churnam lab and marketed formulation and its ingredients with reference to the air dried material. The result obtained for total ash, acid insoluble ash and water-soluble ash are tabulated in Table 5.

Table 5: Percentage Ash Value of Amalki Rasayan Churnam \& its Ingredients

\begin{tabular}{|l|l|l|l|l|}
\hline S.No. & Name & $\begin{array}{l}\text { Total Ash* } \\
(\mathbf{\%} \text { w/w) }\end{array}$ & $\begin{array}{l}\text { Acid Insoluble Ash* } \\
(\mathbf{\%} \mathbf{w} / \mathbf{w})\end{array}$ & $\begin{array}{l}\text { Water Soluble Ash* } \\
\mathbf{( \% ~ w / w ) ~}\end{array}$ \\
\hline $\mathbf{1 .}$ & AM & $6.486 \pm 0.382$ & $1.982 \pm 0.127$ & $2.588 \pm 0.426$ \\
\hline $\mathbf{2 .}$ & AMS & $1.456 \pm 0.217$ & $0.872 \pm 0.048$ & $0.986 \pm 0.235$ \\
\hline $\mathbf{3 .}$ & AMR-I & $6.279 \pm .312$ & $1.846 \pm 0.245$ & $2.392 \pm 0.845$ \\
\hline $\mathbf{4 .}$ & AMR-II & $6.584 \pm 0.248$ & $1.632 \pm 0.184$ & $2.288 \pm 0.413$ \\
\hline $\mathbf{5 .}$ & AMR-III & $6.789 \pm 0.411$ & $2.811 \pm 0.446$ & $1.892 \pm 0.456$ \\
\hline $\mathbf{6 .}$ & MAMR & $6.824 \pm 0.621$ & $3.282 \pm 0.129$ & $2.584 \pm 0.218$ \\
\hline
\end{tabular}

*mean \pm S.D. $\mathbf{n}=3$

The extractive values of amla and amlaki rasayana were recorded in alcohol and water using cold maceration method (Table 6). Details of the proposed method are described previously in materials and methods section.

Table 6: Extractive Values of Amalki Rasayan Churnam \&Amla

\begin{tabular}{|c|c|c|c|}
\hline S.No. & Name & $\begin{array}{l}\text { Alcohol Soluble Extractive } \\
(\% \mathrm{w} / \mathrm{w})\end{array}$ & $\begin{array}{c}\text { Water Soluble Extrative } \\
(\% \mathrm{w} / \mathrm{w})\end{array}$ \\
\hline 1. & $\mathrm{AM}$ & $42.126 \pm 1.347$ & $53.426 \pm 1.282$ \\
\hline 2. & AMR-I & $43.247 \pm 1.284$ & $54.188 \pm 3.725$ \\
\hline 3. & AMR-II & $44.108 \pm 1.486$ & $53.988 \pm 2.722$ \\
\hline 4. & AMR-III & $45.208 \pm 2.104$ & $53.524 \pm 1.082$ \\
\hline 5. & MAMR & $44.288 \pm 1.848$ & $53.682 \pm 1.864$ \\
\hline
\end{tabular}

Tap density, Bulk density, Angle of Repose, Hausner ratio and Carr's Index of the lab formulation, its marketed formulation and ingredients were established through the method discuss and data are tabulated in a Table 7.

Table 7: Rheological Evaluation of Amalki Rasayan Churnam \&Amla

\begin{tabular}{|l|l|l|l|l|l|l|}
\hline S.No. & Name & $\begin{array}{l}\text { Tap } \\
\text { density* }\end{array}$ & $\begin{array}{l}\text { Bulk } \\
\text { density* }\end{array}$ & Angle of repose* & $\begin{array}{l}\text { Hausner } \\
\text { ratio* }\end{array}$ & Carr's index's* \\
\hline 1. & AM & $0.53 \pm 0.02$ & $0.46 \pm 0.01$ & $28.89 \pm 0.62$ & $1.15 \pm 0.01$ & $12.88 \pm 0.22$ \\
\hline 2. & AMR-I & $0.56 \pm 0.03$ & $0.42 \pm 0.02$ & $41.44 \pm 0.72$ & $1.33 \pm 0.03$ & $22.24 \pm 0.12$ \\
\hline $\mathbf{3 .}$ & AMR-II & $0.54 \pm 0.03$ & $0.41 \pm 0.03$ & $39.32 \pm 0.35$ & $1.31 \pm 0.03$ & $20.34 \pm 0.52$ \\
\hline $\mathbf{4 .}$ & AMR-III & $0.62 \pm 0.04$ & $0.49 \pm 0.04$ & $36.52 \pm 0.37$ & $1.26 \pm 0.02$ & $23.72 \pm 0.32$ \\
\hline 5. & MAMR & $0.57 \pm 0.03$ & $0.45 \pm 0.03$ & $37.72 \pm 0.67$ & $1.27 \pm 0.03$ & $21.78 \pm 0.62$ \\
\hline
\end{tabular}

${ }^{*}$ mean \pm S.D. $\mathbf{n}=3$

\section{CONCLUSION}

In this work, Amalaka churnam is evaluated according to standard procedures. Initially, organoleptic properties of the material have been evaluated later on extractive values, phytochemical and rheological evaluation has been calculated. The standard established for the formulation can be used as reference by Ayurvedic manufacturers for quality assessment and improvement of their formulations quality.

\section{REFERENCES}

[1] Archana A., Bele, Anubha K. Standardization of Herbal Drugs: An overview. Int Res J Pharm 2011;2:56-60. doi:ISSN:22308407.

[2] Department of Indian system of medicine and homeopathy:Department of family walfare, Government of India, Formulary of India. 2002.

[3] Venkateswarlu G, Ganapaty S, Sudhakar AMS. Preparation of Triphala Churna using the Ingredients Obtained from Local Market and Comparative Standardization. Pharmacogn J 2019;11:102-11. doi:10.5530/pj.2019.1.18.

[4] The Indian Herbal Pharmacopoeia. New Delhi: A Joint
Publication Of Regional Research Laboratory, Indian Drug Manufacturers Association. 1998.

[5] Soni H, Bhatt S, Patgiri B. Standardization of Rasayana Churna - A classical Ayurvedic formulation. Int J Res Pharm Sci 2013;4:283-9.

[6] Patra KC, Jayaram Kumar J, Suresh P. Standardization of a polyherbal Siddha formulation, Amukkara Choornam. Indian J Tradit Knowl 2009;8:449-52.

[7] Baragi U, Baragi P, Vyas M, Shukla V. Standardization and quality control parameters of Dashanga Kwatha ghana tablet: An Ayurvedic formulation. Int J Ayurveda Res 2011;2:42. doi:10.4103/0974-7788.83190.

[8] WHO: General Guidelines for methodologies on research and evaluation of traditional medicines: Geneva, World Health Organization. 2002.

[9] Singh NK, Kumar P, Gupta DK, Singh S, Singh VK. UVspectrophotometric method development for estimation of piperine in Chitrakadi Vati. Der Pharm Lett 2011;3:178-82.

[10] Nikam PH, Kareparamban J, Jadhav A, Kadam V. Future trends in standardization of herbal drugs. J Appl Pharm Sci 2012;2:38-44. doi:10.7324/JAPS.2012.2631.

[11] Yadav YN, Dixit VK. Recent Approaches in herbal drug standardization. Int J Integr Biol 2008;2:195-203. 